\title{
CHARACTERIZATION OF CROP/LIVESTOCK FARMING SYSTEM IN NEW VALLEY OF EGYPT
}

\author{
Mona Mohammady I. ${ }^{\text {*, }}$ M.N.M. Abd El-Ati' ${ }^{2}$ H. Hamdon ${ }^{3}$ and Doaa A. Abd El-Salam ${ }^{1}$ \\ 1- Animal Production and Poultry Division, Desert research Center, 2- Department of Animal Production, Assiut \\ University, 3- Department of Animal Production, New Valley University \\ *Corresponding author, Email: monamohammady@hotmail.com
}

The current study adopted system approach to characterize the current crop/livestock farming system of small scale farms and to assess its economical efficiency in the New Valley Governorate of Egypt. Four districts were identified, Elkharga, Eldakhla, Baris and Balat. A random sample of 120 farms was taken to represent the four studied districts (30 farms from each district). A questionnaire was designed to cover available production resources, farming activities, variable costs and revenues. Data were collected over the agricultural year from September 2015 to August 2016. Least squares analysis of variance technique using a fixed effects linear model was performed to derive technical coefficients of the considered productive traits for livestock and major crops. Whole farm budget was applied for financial assessment to determine the overall gross margin $(\mathrm{GM})$ per feddan and benefit/cost ratio $(\mathrm{B} / \mathrm{C})$ of the four studied districts. Averages farm size were 7.17 feddan, 8.62 feddan, 4.45 feddan and 10.72 feddan for Elkharga, Eldakhla, Baris and Balat, respectively. Results showed that daily milk yield per head of cow were estimated as $3.29 \mathrm{~kg}, 2.45 \mathrm{~kg}, 1.78 \mathrm{~kg}$ and $1.99 \mathrm{~kg}$ for Elkharga, Eldakhla, Baris and Balat, respectively. On the other hand, the corresponding total milk yield of cow was estimated as $773 \mathrm{~kg}, 515 \mathrm{~kg}, 338 \mathrm{~kg}$ and $398 \mathrm{~kg}$, respectively. Common crops in winter season were Alfalfa, wheat, barley and bean. While in summer season were Elephant grass, darawa, w-corn, cowpeas, fume and cash crops. The obtained values of the farm GM per feddan revealed that farmers of Baris district utilized their limited production resources more efficient than the other studied districts and achieved the highest gross margin per feddan with estimate of LE 15078, while the lowest was Balat district and achieved LE 4188 per feddan. The farm B/C ratio showed that Eldakhla district earned the highest return per unit of money with estimate of 2.22 ratio.

Keywords: System approach, crop/livestock, gross margin, New Valley governorate, Egypt 